\title{
Congenital thrombotic thrombocytopenic purpura
}

INSERM

\section{Source}

INSERM. (1999). Orphanet: an online rare disease and orphan drug data base. Congenital thrombotic thrombocytopenic purpura. ORPHA:93583

Cong enital thrombotic thrombocytopenic purpura is the hereditary form of thrombotic thrombocytopenic purpura (TTP; see this term) characterized by profound peripheral thrombocytopenia, microangiopathic hemolytic anemia (MAHA) and sing le or multiple organ failure of variable severity. 